\title{
熱水変質帯地すべりの地質的特徵－北海道生田原南地すべり地域の例一 Geological characteristics of hydrothermal alteration zone landslides : Example from the Ikutahara-Minami landslide area, Hokkaido, Japan
}

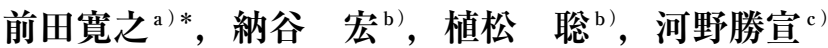

Hiroyuki MAEDA, Hiroshi NAYA, Satoshi UEMATSU and Masanori KOHNO

\begin{abstract}
One ancient large-scale landslide, as well as recent small-scale and ancient middle-scale landslides in the Ikutahara-Minami landslide prevention area can be classified as hydrothermal alteration zone landslides (HAZLs) based on their bedrock geology, and as hydrothermally altered rockslide, and as debris or earth slide, respectively, based on the landslide body. The large-scale HAZL occurred on the hydrothermally argillized zone composed of the smectite-analcite subzone of early-stage regional hydrothermal alteration and the illite-interstratified illite/smectite mineral subzone of early-stage neutral-type vein-related alteration in the Kitanooh fossil hydrothermal system. The middle-and small-scale HAZLs occurred on the smectite-clinoptilolite subzone of the earlystage regional hydrothermal alteration and the K-feldspar, illite, and interstratified illite/smectite mineral zones of the early-stage neutral-type vein-related alteration. The bedrock of the K-feldspar and illite zones, in particular, contains characteristic swelling clay minerals such as interstratified illite/smectite minerals and smectite. The HAZL occurrence, therefore, is closely related to the swelling clay minerals-bearing hydrothermal alteration zones, regardless of the size of the landslides.

Key words : hydrothermal alteration zone landslide (HAZL), hydrothermally altered rockslide, debris slide, earth slide, swelling clay minerals

\section{和文要旨}

生田原南地すべり地域の古期大規模地すべりとその脚部の生田原南地すべり防止区域における古期中規模および最近の小規模地 すべりは，基岩地質による分類では，熱水変質帯地すべり，また，移動体構成物質による分類では，それぞれ熱水変質岩地すべり と, 岩屑地すべりまたは土砂地すべりである。古期大規模地すべりは, 主に北ノ王化石熱水系前期ステージ広域変質帯のスメクタ イトーアナルサイト亜帯と同前期ステージ脈際中性带のイライトーイライト／スメクタイト混合層鉱物亜帯からなる熱水性粘土化 帯で発生している。一方，生田原南地すべり防止区域の中規模および小規模地すべりは，前期ステージ広域変質帯のスメクタイト ークリノタイロライト亜帯と, 前期ステージ脈際中性帯のカリ長石帯, イライト帯拉よびイライト／スメクタイト混合層鉱物带で 発生しているが，カリ長石帯やイライト帯においてもイライト/スメクタイト混合層鉱物やスメクタイトを特徴的に含む。したがっ て，熱水変質帯地すべりの発生は，規模の大小を問わず，膨潤性粘土鉱物を含む熱水変質带と密接な関係を持つ。 キーワード：熱水変質帯地すべり，熱水変質岩地すべり，岩屑地すべり，土砂地すべり，膨潤性粘土鉱物
\end{abstract}

\section{1. 緒 言}

北海道オホーツク総合振興局紋別郡遠軽町生田原市街 地東部に隣接する山腹から山麓には，滑落崖の高さ約 80 $\mathrm{m}$ ，幅約 $800 \mathrm{~m}$ ，全長約 $1,800 \mathrm{~m}$ の古期大規模地すべり地 形が見られ (図-1)，この地すべりのすべり面粘土 (有 機質シルト） から $19,750 \pm 90 \mathrm{yr} B P$ B ${ }^{14} \mathrm{C}$ 年代が得られて いる ${ }^{1)}$ 。この古期大規模地すべり移動体脚部の標高180〜 $245 \mathrm{~m}$ の斜面において, 幅 $800 \mathrm{~m}$, 奥行き $150 \mathrm{~m}$ の $10.85 \mathrm{ha}$


の地すべり防止区域における五つの地すべりと二つの崩 壊をそれぞれ生田原神社地すべり，生田原野球場地すべ り，生田原公園地すべり，F地すべりおよびH地すべり と, C崩壊およびG崩壊と仮称し ${ }^{1), 2}$ (図-2), これら の規模および基岩の熱水変質帯を表 - 1 に示す。また, これらの地域を生田原南地すべり地域と呼ぶことにする。 ここで, 熱水変質帯地すべりとは, 地すべりの地質学

* 連絡著者/corresponding author

a ) 国立大学法人北見工業大学工学部社会環境工学科

Department of Civil and Environmental Engineering, Faculty of Engineering, National University Corporation Kitami Institute of Technology

于090-8507 北海道北見市公園町165 165, Koen-cho, Kitami 090-8507, Japan

b) 明治コンサルタント (株)

Meiji Consultants Co. Ltd

c) 国立大学法人北見工業大学大学院工学研究科

Graduate School of Engineering, National University Corporation Kitami Institute of Technology
的分類の一つであり，地質時代および歴史時代の火山一 熱水系によって形成された熱水変質帯で発生する地すべ りのことである ${ }^{3-6)}$ 。温泉地すべり ${ }^{7)}$ や火山性地すべり (噴 気変質帯型地すべりおよび旧変質帯型地すべり $)^{8}$ はこの 熱水変質带地すべりに相当する。例えば，日本における 熱水変質带地すべりには，青森県浅虫温泉および八甲田 地すべり，宮城県鬼首温泉および鳴子温泉地すべり，群 馬県万座および熊池地すべり，神奈川県早雲山および大 涌谷地すべり，大分県明䙪地すべりなどがある ${ }^{7), 9,10)}$ 。 これらの熱水変質帯地すべりは主に活熱水系に由来する 噴気ガスによって形成された酸性熱水変質帯において発 生した。2001年万座地すべり（狭義）および熊池崩壊一 流動は, 台風の接近に伴う豪雨によって, 草津一白根活 火山の熱水系によって形成された中性および酸性熱水変 質帯において発生した ${ }^{10)}$ 。また，熱水変質帯地すべりは， 四国における中央構造線に沿う熱水性スメクタイト帯や スメクタイトを含む混合層鉱物帯においても発生してい $3^{11,12)}$ 。一方，筆頭著者は，これまで，熱水変質帯の帯 状配列と地すべり地形分布との関係を検討し，熱水変質 帯地すべりは主に膨潤性粘土鉱物で特徵づけられるイラ イトノスメクタイト混合層鉱物帯およびスメクタイト帯 や膨潤性粘土鉱物を含むゼオライト帯と密接であること 


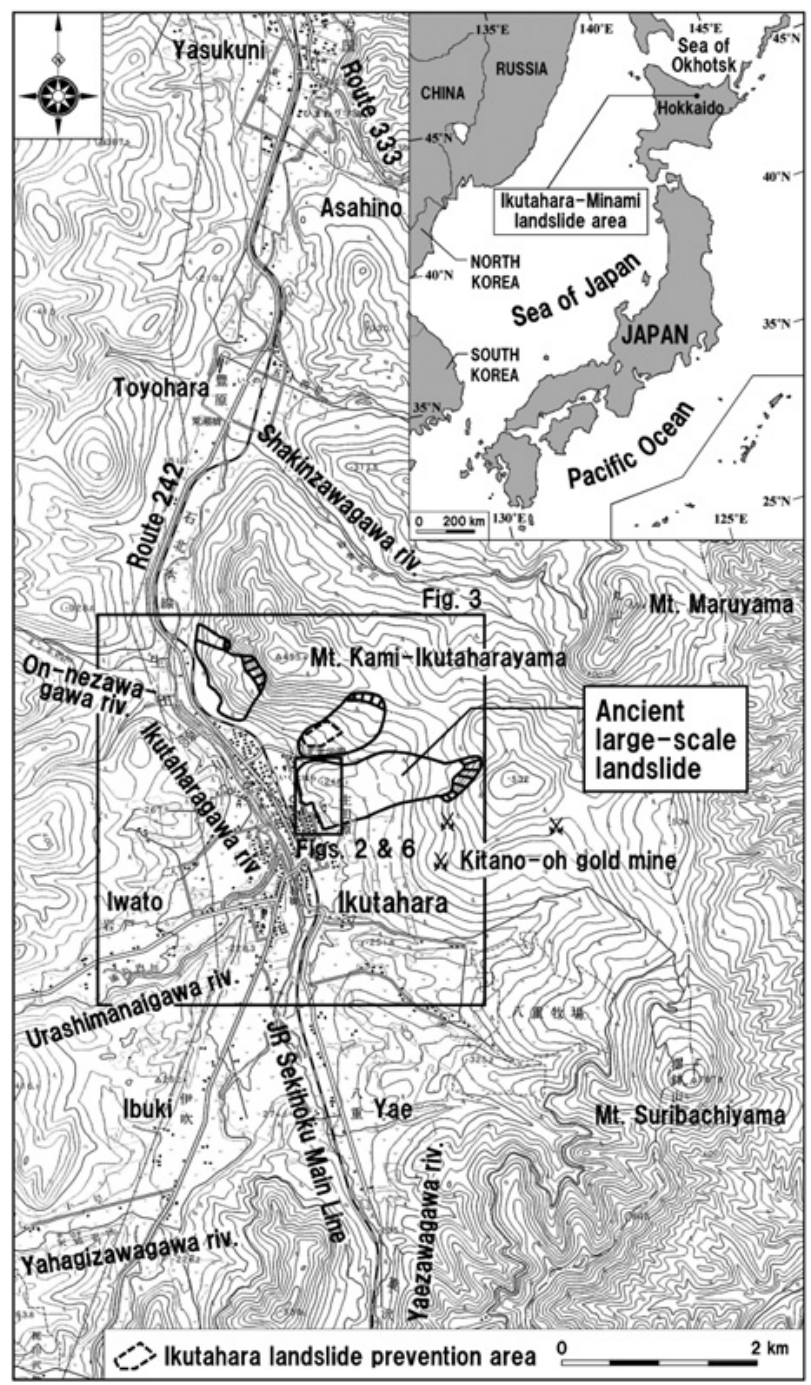

図一1 北海道生田原地すべり防止区域および生田原南地す べり防止区域位置図と古期大規模地すべり地形図 （国土地理院発行 5 万分の 1 地形図「生田原」を使用）

Fig. 1 Location map of the Ikutahara and IkutaharaMinami landslide prevention areas and an ancient large-scale landslide topographic map in Engaru Town, northeastern Hokkaido, Japan. The topographical map is part of a 1:50,000 map of lkutahara from the Geographical Survey Institute of Japan.
を明らかにしてきた ${ }^{2,3), 66,13-21)}$ 。具体的には，熱水変質帯 地すべりは，北海道北東部，遠軽町生田原一北見市留辺 䔉町金華地域の上部中新統生田原層および矢知層分布域 ではイライト/スメクタイト混合層鉱物帯やスメクタイ

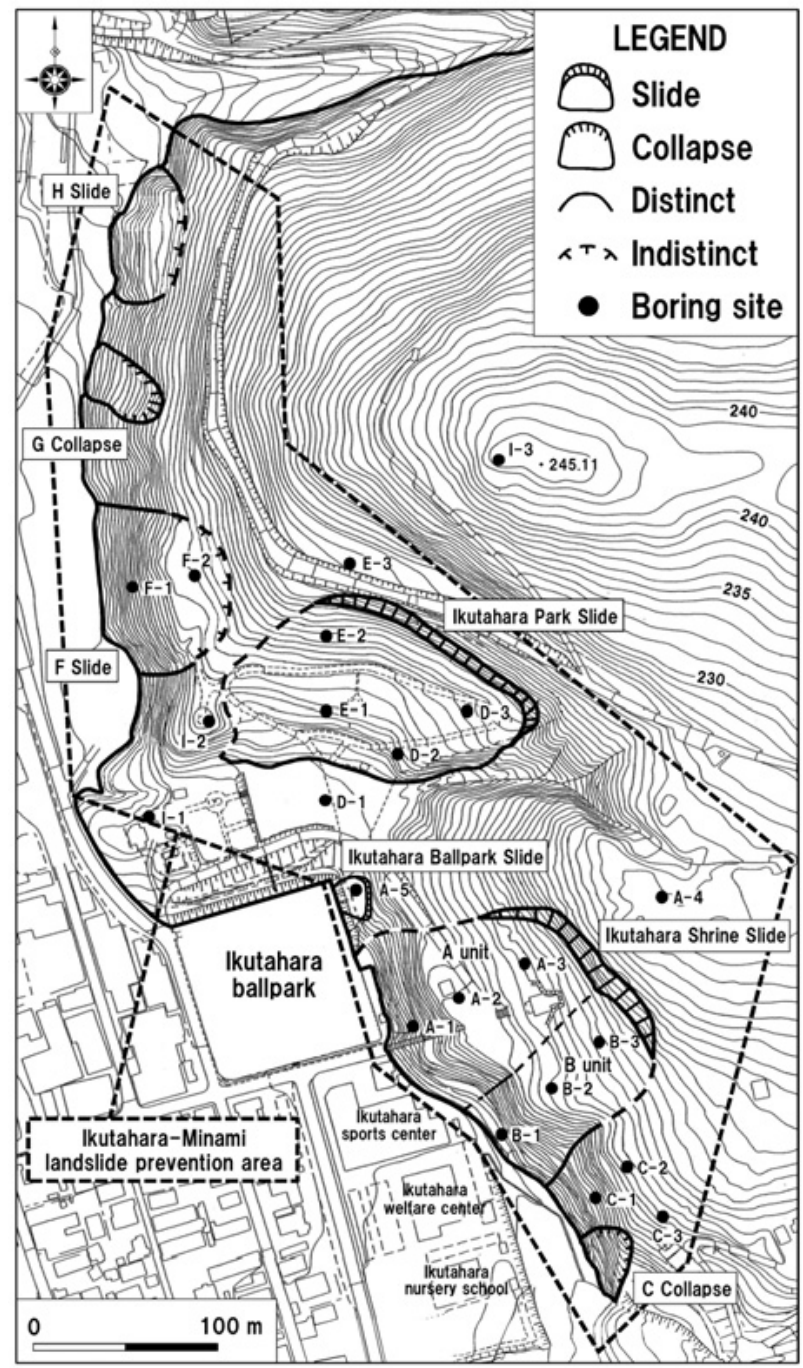

図一２生田原南地すべり防止区域における地すべり地形図 およびボーリング位置図

Fig. 2 Landslide topographic map and boring site map in the Ikutahara-Minami landslide prevention area

表一 1 生田原南地すべり防止区域における地すべりおよび崩壊の特徵

Table 1 Characteristics of landslides in the Ikutahara-Minami landslide prevention area

\begin{tabular}{|c|c|c|c|c|}
\hline Landslide name & $\begin{array}{l}\text { Width } \\
(\mathrm{m})\end{array}$ & $\begin{array}{l}\text { Total length } \\
(\mathrm{m})\end{array}$ & $\begin{array}{l}\text { Height of scarp } \\
\text { (m) }\end{array}$ & $\begin{array}{c}\text { Hydrothermal alteration zone } \\
\text { developed in bedrock }\end{array}$ \\
\hline Ikutahara Shrine Slide & 150 & 140 & 2.0 & $\mathrm{III} / \mathrm{Smc}, \mathrm{Kfs}-\mathrm{III} / \mathrm{Smc}$, and Kfs-III \\
\hline Ikutahara Ballpark Slide & 25 & 20 & 1.5 & $\mathrm{Kfs}-\mathrm{III} / \mathrm{Smc}$ \\
\hline Ikutahara Park Slide & 150 & 100 & 2.0 & $\mathrm{Kfs}-\mathrm{III}, \mathrm{Kfs}-\mathrm{III} / \mathrm{Smc}$, and $\mathrm{Kfs}-\mathrm{Smc}$ \\
\hline F Slide & 120 & 70 & 3.5 & Smc-Cpt \\
\hline H Slide & 80 & 40 & 2.0 & Kfs-III \\
\hline C Collapse & 10 & 10 & 0.5 & $\mathrm{Kfs}-\mathrm{III} / \mathrm{Smc}$ and $\mathrm{Kfs}-\mathrm{Smc}$ \\
\hline G Collapse & 30 & 50 & 1.0 & Kfs-III \\
\hline
\end{tabular}

Abbreviations : III/Smc = interstratified illite/smectite mineral zone, Kfs-III = K-feldspar-illite subzone,

$\mathrm{Kfs}-\mathrm{III} / \mathrm{Smc}=\mathrm{K}$-feldspar-interstratified illite $/$ smectite mineral subzone, $\mathrm{Kfs}-\mathrm{Smc}=\mathrm{K}$-feldspar-smectite subzone, Smc-Cpt=smectite-clinoptilolite subzone. 
ト帯 ${ }^{3)}$ のほか，カオリン鉱物帯およびイライト帯 ${ }^{3}$ やスメ クタイトを含むモルデナイト帯 ${ }^{13)}$ で，また，北海道東部， 弟子屈町札友内一奧春別地域の上部中新統オテシカウシ ナイ層分布域ではイライト／スメクタイト混合層鉱物 帯 ${ }^{18)}$ で，同ハナクシベ層およびシケレぺ層分布域ではス メクタイト帯，スメクタイトを含むモルデナイト帯およ びスメクタイトを含むローモンタイト帯 ${ }^{6}$ で発生してい る。生田原地すべり防止区域（図－2）では，古期地す ベり基岩がスメクタイトを含むモルデナイト帯である ${ }^{13)}$ のに対して，生田原南地すべり地域の古期大規模地すべ りでは，すべり面粘土がスメクタイトを含むアナルサイ 卜帯起源である ${ }^{2)}$ 。ただし，熱水変質帯地すべりは，こ れらの熱水変質带の全域で発生している訳ではなく, 地 質構造 ${ }^{3,66,22)}$, 特に流れ盤の構造, キャップロック構造, 熱水変質岩の力学的性質 $\left.{ }^{2)}, 22\right)$,23) 水理環境などにも規制 されている。

本論文は, 生田原南地すべり地域の熱水変質帯地すべ りに関する空中写真判読，地表踏査，ボーリング調査お よび粉末X線回折試験デー夕を総合的に解析し，古期大 規模地すべりとその移動体脚部における中規模および小 規模地すべりの地質的特徴を浮彫にすることを目的とし ている。

\section{2. 地質環境の概要}

生田原南地すべり地域の地質は，上部白亜系〜古第三 系暁新統涌別層群を基盤岩とし，主に上部中新統生田原 層および矢知層, 後期中新世の上生田原山流紋岩岩脈類, 第四系更新統山麓緩斜面堆積物, 河成段丘堆積物および
古期地すべり堆積物と，完新統沖積扇状地堆積物，土石 流堆積物および沖積層からなる（図－3）。これらの地 質のうち，地すべりの基岩や移動体は主に生田原層構成 岩である。生田原層は，本地域に広く分布し，主に凝灰 質碟岩，砂岩および泥岩，凝灰岩，火山礫凝灰岩，凝灰 角砂岩，流紋岩溶岩および安山岩溶岩からなる陸成層で ある。これらの岩類は続成作用，熱水変質作用および風 化作用を受けている。生田原層の地質構造はNNW - SSE 方向の褶曲軸を持つ背斜構造および向斜構造で特徵づけ られる(図 - 3 )。

\section{3. 試料および試験方法}

\section{1 試 料}

試料は，主に古期大規模地すべり滑落崖および側方崖 と，移動体脚部とそれらの周辺の地表からハンマーを 使って採集した転石178個と，ボーリングコア119個の熱 水変質岩である。なお，古期大規模地すべりは，ボーリ ング $\mathrm{D}-3$ 号孔（図－2）において，すべり面直下の基 岩が生田原層の上位の矢知層からなり，すべり面直上の 移動体が生田原層起源であることを確認したことと，こ のボーリングサイトと地すべり先端との距離とに基づく と，約 $200 \mathrm{~m}$ 以上移動したとされる が，この地すべり右 側方崖非変動域のスメクタイトーゼオライト帯とイライ トーイライトノスメクタイト混合層鉱物亜帯との境界と, 移動体脚部におけるI- 3 号孔ボーリングサイト（図一 2 ）のスメクタイトーゼオライト帯（図－4，5，6）が ほぼ連続していたと仮定すると，現在の熱水変質帯の分 布も，約 $200 \mathrm{~m}$ 移動したことを支持している。したがっ

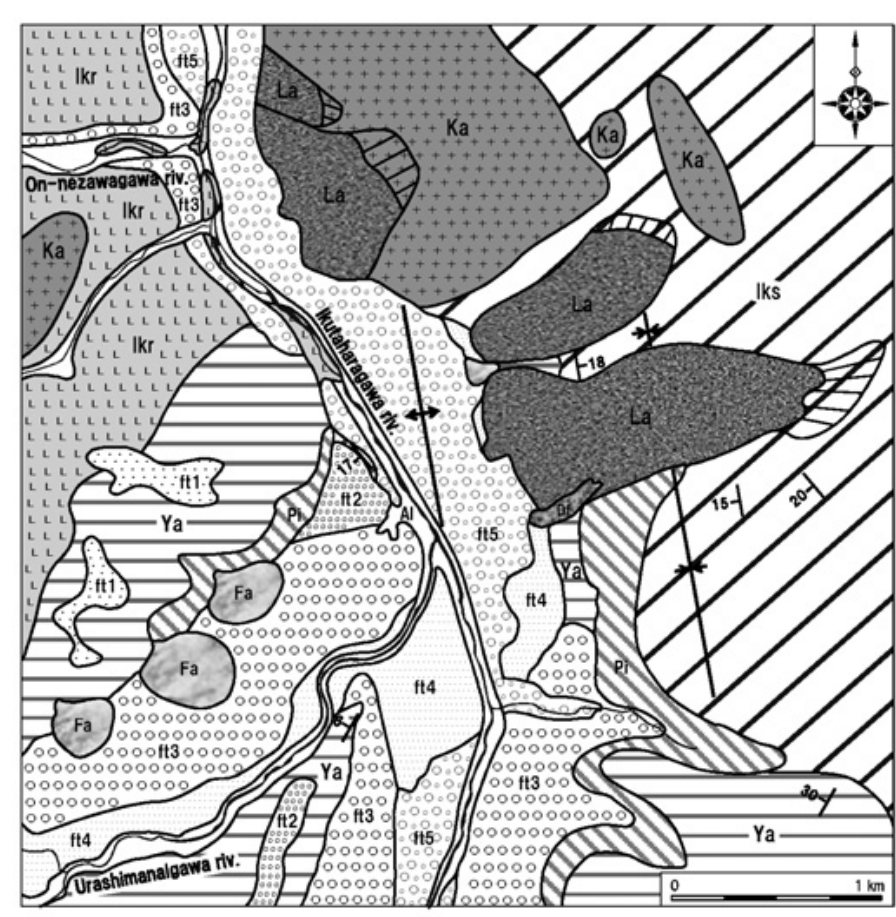

\section{LEGEND}

Holocene Series

Alluvial deposits

Debris flow deposits

Alluvial fan deposits

\section{Pleistocene Series}

Ancient landslide deposits

Fluvial terrace deposits 5

Fluvial terrace deposits 4

Fluvial terrace deposits 3

Fluvial terrace deposits 2

Fluvial terrace deposits 1

\begin{tabular}{l}
\hline Al Gravel, sand, silt, and clay \\
Fot Gravel, sand, silt, and clay \\
Fa Gravel, sand, silt, and clay
\end{tabular}

Piedmont easy slope deposits

Late Miocene dike

Upper Miocene Series

Yahagi Formation

Ikutawara Formation

\section{La Rubble, sand, silt, and clay}

ft5: Gravel, sand, silt, and clay

ft4 Gravel, sand, silt, and clay

$933^{\circ}$ Gravel, sand, silt, and clay

Fit2: Gravel, sand, silt, and clay

fft Gravel, sand, silt, and clay

RU. Rubble, sand, silt, and clay

Ka Kami-Ikutaharayama Rhyolite

$Y_{a}$ Clastic and volcaniclastic rocks

ilkrat Rhyolite dike and lava

Iks. Clastic and volcaniclastic rocks

$y$ Strike and dip

Anticlinal axis

* Synclinal axis

図一３生田原南地すべり地域の地質図

Fig. 3 Geological map of the Ikutahara-Minami landslide area and environs 
て，生田原南地すべり防止区域は現在の位置より約 200 $\mathrm{m}$ 上方斜面上にあったことになり，旧生田原川の浸食作 用などを誘因として古期大規模地すべりが活動して現在 の位置を占めていると考えられる。

\section{2 粉末X線回折試験}

コア試料の岩屑や土砂は, 自然乾燥後，指でほぐして $75 \mu \mathrm{m}$ 未満の細粒分と砂分に分けてデー夕を取った。熱 水変質鉱物は粉末X線回折 (XRD) 法による不定方位デー 夕によって同定した。特に，粘土鉱物は，主な試料につ いて, 水箕によって $2 \mu \mathrm{m}$ 以下の粘土粒子を集め, 定方位 およびエチレングリコール処理データによって同定した。

X線回折装置は株式会社りガク製Rint Ultima ${ }^{+}$を用い, 実験条件はCu K $\alpha ， 30 \mathrm{kV} ， 20 \mathrm{~mA}$ ，時定数 1 秒，スリッ 卜系 $1^{\circ}-0.3 \mathrm{~mm}-1^{\circ}$, 走查速度 $1^{\circ} /$ 分, チャート速 度 $10 \mathrm{~mm} /$ 分，フルスケール1,000c.p.s.である。

\section{4. 結果および考察}

\section{1 地すべり基岩および移動体}

生田原南地すべり地域における古期大規模地すべりと 古期中規模および最近の小規模地すべりの基岩は主に新 第三系上部中新統生田原層の平行葉理や波状葉理を持つ

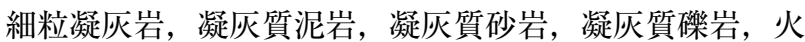
山砂凝灰岩，凝灰角砂岩などからなる。これらの地すべ り基岩は，まず，熱水変質作用によって珪化または粘土
化して白色熱水変質岩となり，次に，風化作用によって 熱水変質岩中の，主にパイライト（黄鉄鉱）がゲーサイ 卜 (針鉄鉱) 化して黄褐色風化岩となっている。それゆ え, 地すべり移動体は主に基岩起源の熱水変質岩, 風化・ 熱水変質岩（熱水変質作用㧍よび風化作用を重複して受 けた岩石)，岩屑，土砂などからなる。岩屑や土砂中の 砂分は，様々な程度に熱水性珪化または粘土化し，さら に風化した, 主に細粒凝灰岩からなるが,シリカシンター や脈石英なども見られる。

\section{2 地質構造と地すべりとの関係}

古期大規模地すべりと基岩の走向・傾斜との関係は, 地すべり移動体頭部〜胴部では $20^{\circ}$ 以下の流れ盤，胴部 ～脚部では $18^{\circ}$ 以下の受け盤の構造であるので，生田原 南地すべり防止区域の中規模および小規模地すべりでは $10^{\circ}$ 程度の受け盤の構造である（図 $-2 ， 3$ )。

\section{3 熱水変質帯と地すべりとの関係}

\subsection{1 熱水変質帯の区分}

本地域は，後期中新世から前期更新世にかけて，陸上 火山－熱水活動が大規模に生じ ${ }^{24)}$ ，後期中新世と前期鮮 新世〜前期更新世の大きく二回の北ノ王浅熱水性金銀鉱 化作用に伴う熱水変質作用を重複して受けている。一回 目に当たる北ノ王化石熱水系前期ステージ（以下，「前 期ステージ」と記す。）熱水変質作用は，広域変質带の スメクタイトーゼオライト帯と, これを切って発達する,

\begin{tabular}{|c|c|c|c|c|c|c|c|c|c|c|c|c|c|}
\hline Stage & \multicolumn{10}{|c|}{ Early stage } & \multirow{2}{*}{\multicolumn{3}{|c|}{$\begin{array}{c}\text { Late stage } \\
\text { Vein-related acid alteration zone }\end{array}$}} \\
\hline \multirow{3}{*}{ Mineral } & \multirow{2}{*}{\multicolumn{3}{|c|}{$\begin{array}{l}\text { Regional alteration zone } \\
\text { Smectite-zeolite zone }\end{array}$}} & \multicolumn{7}{|c|}{ Vein-related neutral alteration zone } & & & \\
\hline & & & & \multirow{2}{*}{$\begin{array}{c}\text { III/Smc } \\
\text { zone }\end{array}$} & \multicolumn{2}{|c|}{ Illite zone } & \multicolumn{4}{|c|}{ K-feldspar zone } & \multirow{2}{*}{$\begin{array}{l}\text { Halloysite } \\
\text { zone }\end{array}$} & \multirow{2}{*}{$\begin{array}{l}\text { Kaolinite } \\
\text { zone }\end{array}$} & \multirow{2}{*}{$\begin{array}{l}\text { Dickite } \\
\text { zone }\end{array}$} \\
\hline & Smc-Cpt & Smc-Mor & Smc-Anl & & $\|I I-\| I / S m c$ & III-Qtz & Kfs-Smc & Kfs-III/Smc & Kfs-III & Kfs-Qtz & & & \\
\hline \multicolumn{14}{|l|}{ Quartz } \\
\hline \multicolumn{8}{|l|}{ Opal-CT } & & & & & & \\
\hline \multicolumn{14}{|l|}{ K-feldspar } \\
\hline \multicolumn{14}{|l|}{ Albite } \\
\hline \\
\hline \multicolumn{14}{|l|}{ Chlorite } \\
\hline \multicolumn{14}{|l|}{ Int. III/Smc } \\
\hline \multicolumn{14}{|l|}{ Smectite } \\
\hline \multirow{2}{*}{\multicolumn{14}{|c|}{$\begin{array}{l}1.0 \mathrm{~nm} \text { Halloysite } \\
0.7 \mathrm{~nm} \text { Halloysite }\end{array}$}} \\
\hline \multirow{2}{*}{\multicolumn{14}{|c|}{ Kaolinite }} \\
\hline & & & & & & & & & & & & & \\
\hline \multicolumn{14}{|l|}{ Dickite } \\
\hline \multicolumn{14}{|l|}{ Nacrite } \\
\hline \multicolumn{14}{|l|}{ Clinoptilolite } \\
\hline \multicolumn{14}{|l|}{ Mordenite } \\
\hline \multicolumn{14}{|l|}{ Analcite } \\
\hline Alunite & & & & & & & & & & & & & \\
\hline Pyrite & & & & & & & & & & & & & \\
\hline
\end{tabular}

図一４生田原南地すべり地域における熱水変質帯の鉱物組合せ (Int. III/Smc：イライト／スメクタイト混合層鉱物, Smc-Cpt： スメクタイトークリノタイロライト亜帯, Smc-Mor：スメクタイトーモルデナイト带帯, Smc-Anl：スメクタイトーア ナルサイト亜帯, III/Smc zone：イライト/スメクタイト混合層鉱物帯, IIIIIII/Smc：イライトーイライト/スメクタイ 卜混合層鉱物亜帯, III-Qtz：イライトー石英亜帯, Kfs-Smc：カリ長石ースメクタイト重帯, Kfs-III/Smc：カリ長石ー イライト /スメクタイト混合層鉱物亜帯, Kfs-III：カリ長石ーイライト亜帯, Kfs-Qtz：カリ長石一石英亜帯)

Fig. 4 Mineral assemblages of hydrothermal alteration zones in the Ikutahara-Minami landslide area. Int. III/Smc=interstratified illite/smectite minerals ; Smc-Cpt=smectite-clinoptilolite subzone ; Smc-Mor=smectite-mordenite subzone ; Smc-Anl=smectite-analcite subzone ; III/Smc zone=interstratified illite/smectite mineral zone ; III-III/Smc=illite-inter stratified illite/smectite mineral subzone; III-Qtz=illite-quartz subzone; Kfs-Smc=K-feldspar-smectite subzone ; $\mathrm{Kfs}-\mathrm{III} / \mathrm{Smc}=\mathrm{K}$-feldspar-interstratified illite/smectite mineral subzone ; Kfs-III=K-feldspar-illite subzone ; Kfs-Qtz=Kfeldspar-quartz subzone. 
晶洞質石英脈や石英ーアデュラリア（水長石）脈を胚胎 する脈際中性帯のカリ長石带，イライト帯およびイライ 卜ノスメクタイト混合層鉱物帯とで特徵づけられる（図 $-4)$ 。一方，二回目に当たる北ノ王化石熱水系後期又 テージ（以下，「後期ステージ」と記す。）熱水変質作用 は, 前期ステージ熱水変質带を切って発達する, 石英一 アルナイト（明バン石）脈や石英ーディッカイト脈を胚 胎する脈際酸性帯のデイッカイト帯，カオリナイト帯お よびハロイサイト帯で特徵づけられる（図－4）。

古期大規模地すべりおよび生田原南地すべり防止区域 の中規模および小規模地すべりの基岩および移動体から 同定された熱水変質釷物および熱水変質帯の鉱物組合せ を図-4に，地表熱水変質带分布図を図 -5 および図 6 に，生田原神社地すべり北側の $\mathrm{A}$ ユニットにおける熱 水変質帯挹よび風化帯の縦断面図を図 - 7 に示す。

熱水変質帯のうち, 酸性帯は, 古期大規模地すべり滑 落崖付近にはよく発達するが，生田原南地すべり防止区 域ではほとんど見られない（図-5，6）ので，次の各熱 水変質帯の記載では酸性帯を省略する。

カリ長石帯は，生田原南地すべり地域に打いて比較的 広く分布し（図-5，6，7），石英拈よびカリ長石を主と する珪化带であるが, 少量のイライト, クローライト (緑 泥石)，イライト/スメクタイト混合層鉱物，スメク夕 イト，パイライトなどを伴う。この変質帯は，粘土鉱物 が不定方位XRD試験の検出限界未満の場合をカリ長石 一石英亜帯，また，それが検出限界以上の場合には，共 生粘土鉱物に基づくと，カリ長石一イライト亜帯，カリ 長石一イライト/スメクタイト混合層鉱物亜帯およびカ リ長石ースメクタイト亜带に細分される（図－4）。

イライト带は，古期大規模地すべり滑落崖抒よび右側 方崖の非変動域に比較的広く分布する（図－5）ととも に，生田原南地すべり防止区域南部ではカリ長石一イラ イト亜带中に局所的に（図-6)，また，生田原神社地 すべり Aユニット縦断面では比較的広く (図- 7 ) 分布 する。この変質帯は，石英执よびイライトを主とし，少 量のクローライト，イライト/スメクタイト混合層鉱物, スメクタイト，パイライトなどを伴い（図-4),また，
イライト/スメクタイト混合層鉱物を含まないイライト 一石英亜带の珪化帯とそれを含むイライトーイライト／ スメクタイト混合層鉱物亜带の粘土化帯とに細分される

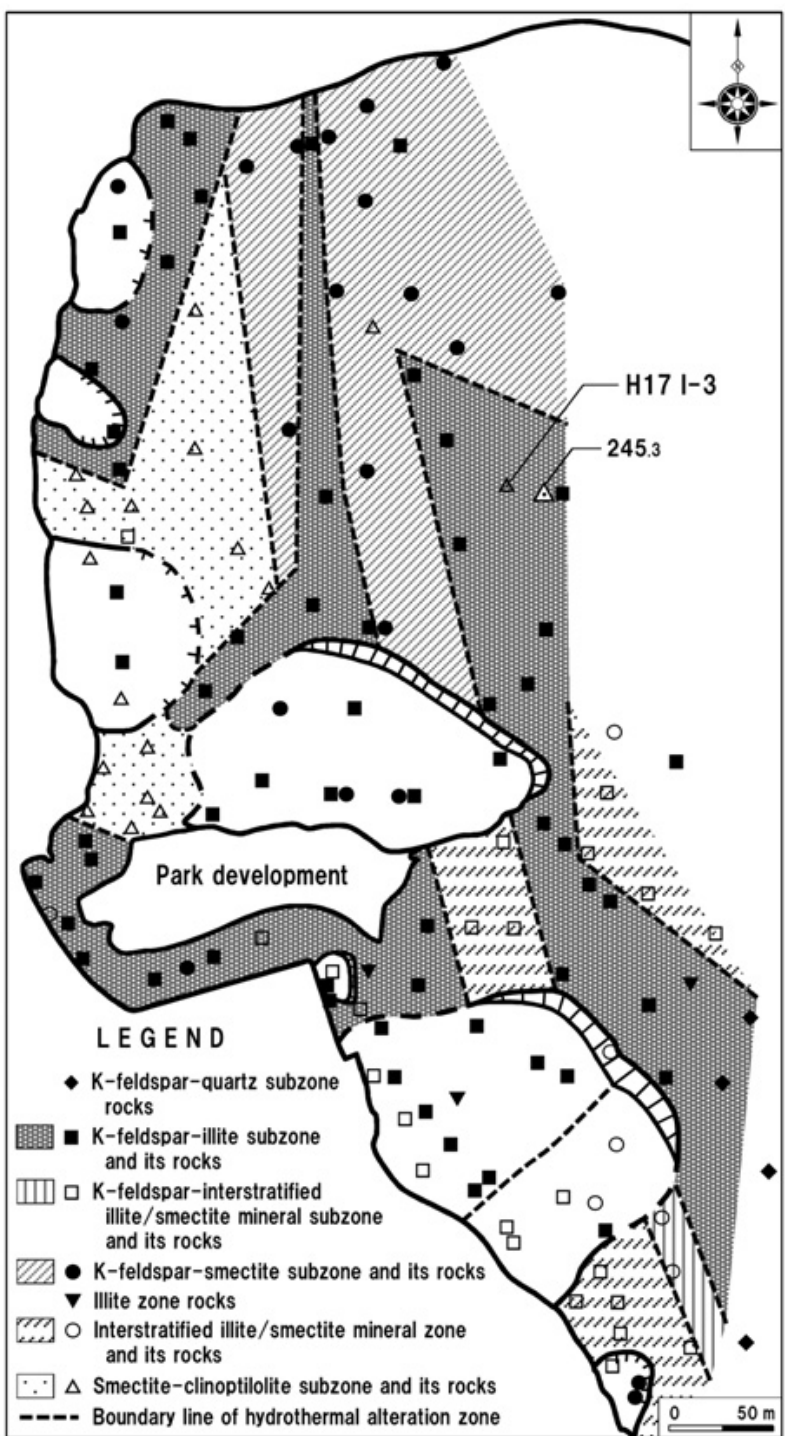

図一６生田原南地すべり防止区域における地表熱水変質帯 分布図

Fig. 6 Distribution of hydrothermal alteration zones in the Ikutahara-Minami landslide prevention area

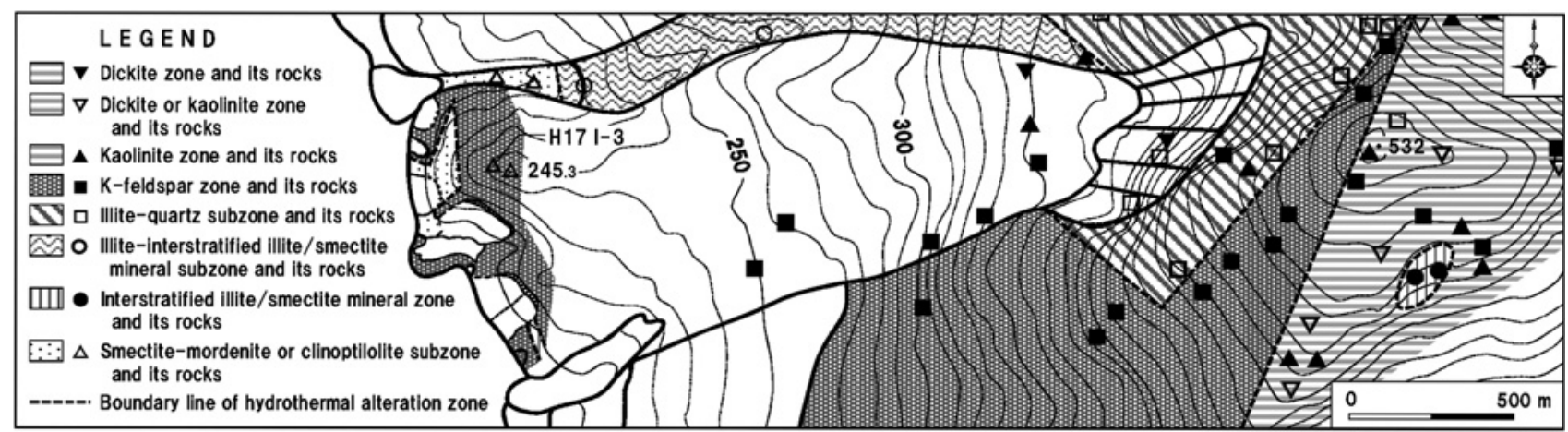

図ー5 生田原南地すべり地域の古期大規模地すべり周辺における地表熱水変質帯分布図

Fig. 5 Distribution of hydrothermal alteration zones in the ancient large-scale Ikutahara-Minami landslide area and environs 


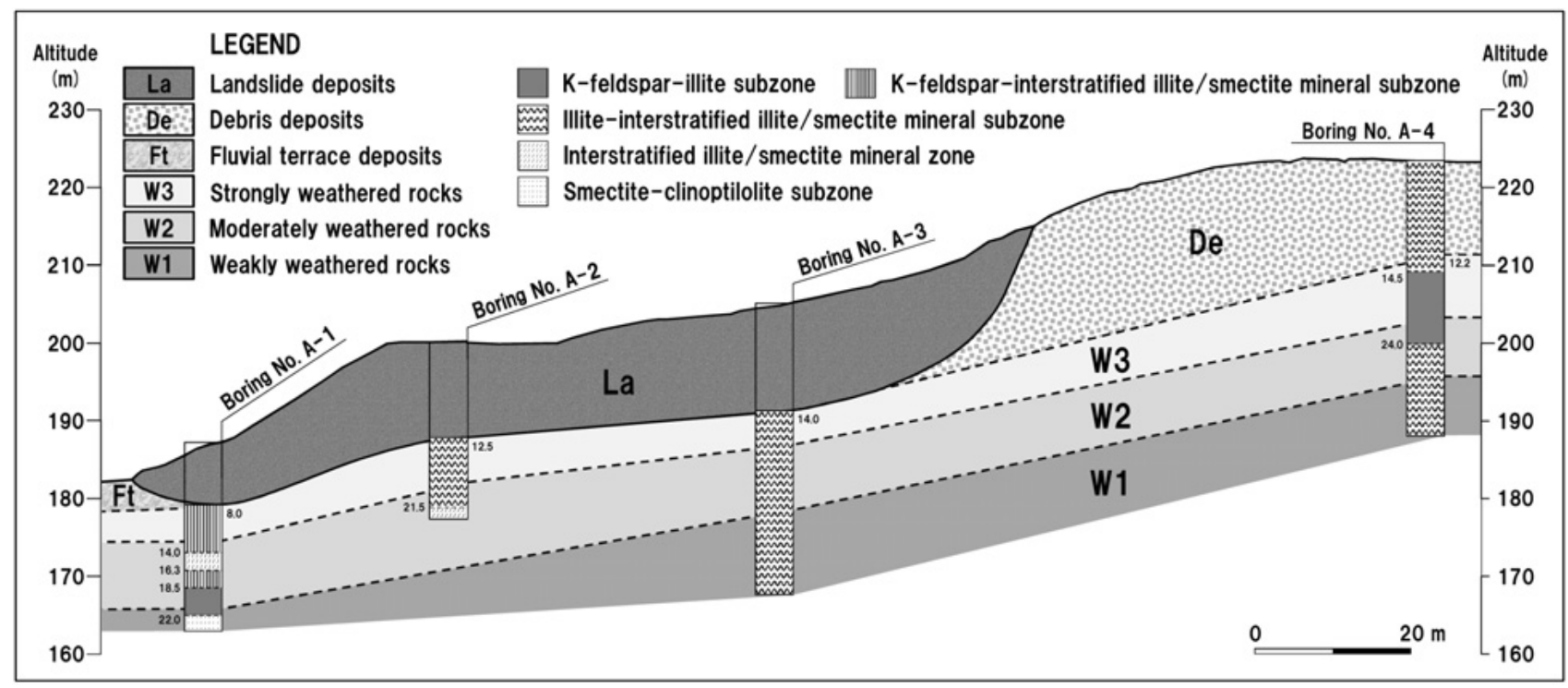

図ー7 生田原神社地すべりAユニットにおける熱水変質帯および風化帯の縦断面図

Fig. 7 Profile of hydrothermal alteration zones and weathering zones in an A unit of the Ikutahara Shrine Slide

(図-4)。

イライトノスメクタイト混合層鉱物帯は，生田原南地 すべり防止区域南部ではカリ長石ーイライト亜帯やカリ 長石ーイライトノスメクタイト混合層鉱物亜帯と帯状に 配列する（図－6）。この変質帯は，石英およびイライ トノスメクタイト混合層鉱物を主とし，少量のクローラ イト，スメクタイト，アナルサイト (方沸石)，パイラ イトなどを伴う粘土化帯である（図－4）。

スメクタイトーゼオライト帯は生田原南地すべり地域 西部において狭く分布し（図-5，6），スメクタイトを 主とし，少量のオパールA，オパールCT，石英，クリ ノタイロライト（斜プチロル沸石），モルデナイト（モ ルデン沸石)，アナルサイト，パイライトなどを伴う粘 土化帯である。この変質帯は，共生ゼオライトに基づく と，スメクタイトーアナルサイト亜帯，スメクタイトー モルデナイト亜帯およびスメクタイトークリノタイロラ イト亜帯に細分される（図-4，6）。

\section{3.2 熱水変質帯の帯状配列と地すべりとの関係}

（1）古期大規模地すべり地域

古期大規模地すべりの基岩は主に生田原層の熱水変質 火砕岩や砕首岩からなる。滑落崖は, 急斜面で, NE-SW 方向を持ち（図一 1，5），シリカシンターや晶洞質石英 細脈や網状脈を胚胎する，前期ステージ脈際中性帯のカ リ長石 - 石英亜带やイライトー石英亜帯と後期ステージ 脈際酸性帯のディッカイト帯が重複して形成された珪化 帯に支配されている（図－5）。一方，右側方崖の非変 動域は，緩斜面で，その上部から下部へ，大部分イライ トーイライト /スメクタイト混合層鉱物亜帯およびスメ クタイトーモルデナイト亜帯やスメクタイトークリノタ イロライト亜帯の熱水性粘土化帯であるのに対して，左 側方崖の非変動域の上部は, 比較的急斜面で, ENEWSWに伸長した，主にカリ長石一石英亜帯からなる珪
化帯であり，その下方斜面は北ノ王金山操業時に地形改 変され, 現在, 牧草地のため, 詳細不明である(図 -5$)$ 。 したがって，この地すべりは，滑落崖と左側方崖の上部 が少なくとも珪化帯と粘土化帯の境界に支配され，全体 として粘土化帯において発生したと考えられる。特に， 滑落崖およびその上方斜面の珪化帯中には, 晶洞質石英 細脈や網状脈が胚胎するため，主にその晶洞中に包蔵さ れた地下水が滑落崖へ供給され，地下水脈は大きく左右 の側方崖に沿って流下すると推定される。それゆえ，主 に地すべり移動体の熱水性粘土化岩は，滑落崖および側 方崖から供給された地下水の化学的風化作用によって風 化・熱水変質岩となり, 風化生成のゲーサイトなどの粘 土分が増加するとともに，点載荷強さや一軸圧縮強さな どの力学的性質が小さくなると考えられる。したがって， 地すべり移動体は熱水性粘土化作用と風化による粘土化 作用を重複して受けていると考えられる。

熱水変質帯の伸長方向は，滑落崖ではNE-SWである が, 移動体頭部〜脚部の基岩では大部分 $\mathrm{NW}-\mathrm{SE}, \mathrm{NNW}$ - SSE，N-SおよびNNE-SSWであるので，この地す べりは，これらの伸長方向を切って，東北東から西南西 へ移動している。また，この古期大規模地すべり脚部の 標高244.66m地点から総掘進長78.00mの垂直ボーリン グI- 3 号孔が掘削され（図-2），この地すべりのすべ り面はボーリング孔の深度 $62.8 \mathrm{~m}$ の細粒凝灰岩中にある

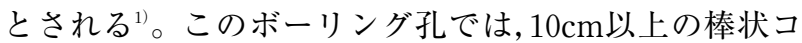
アがほとんどなく，大部分のコアが細かく割れている。 この孔の深度約 $55 \mathrm{~m}$ を境にして下部がスメクタイトーア ナルサイト亜帯，上部がスメクタイトークリノタイロラ イト亜帯であるが，そのすべり面と接する細粒凝灰岩の 鉱物組成は，不定方位XRDデー夕に基づくと，中量の 石英，少量の長石およびスメクタイト，微量のアナルサ イト，クリノタイロライトーヒューランダイト (輝沸石) 
系鉱物などからなる2)。さらに，熱水変質帯のうち，点 載荷強さ減少率が $60 \%$ 以上のイライト/スメクタイト混 合層鉱物帯, スメクタイト帯，イライトーイライト/ス メクタイト混合層鉱物亜帯などの熱水変質岩では, 強制 湿潤状態に扔ける点載荷強さが大幅に低下し, 地表水や 地下水が地盤の強さ低下を促し，地すべりを発生させる 可能性があるとされる ${ }^{24)}$ 。したがって，この地すべり移 動体脚部におけるデー夕と滑落崖抒よび移動体頭部〜胴 部の地形, 地質構造および熱水変質帯データとに基づく と, 古期大規模地すべりは, 滑落崖と左側方崖の上部が カリ長石 - 石英亜带, イライト - 石英亜带, ディッカイ ト帯などの珪化帯とイライトーイライト/スメクタイト 混合層鉱物亜带の粘土化帯との境界に規制され，かつ， 移動体頭部〜胴部の基岩における $20^{\circ}$ 以下の流れ盤と, 胴部一脚部の基岩における $18^{\circ}$ 以下の受け盤の構造に支 配され，また，局所的に珪化带を伴うイライトーイライ トノスメクタイト混合層鉱物亜带やスメクタイトーアナ ルサイト亜帯の熱水性粘土化帯の中の膨潤性粘土鉱物を 含む熱水変質岩をすべり面として発生したと考えられる。 以上のことから, 古期大規模地すべりは, 基岩地質に基 づくと，熱水変質带地すべりに分類でき，また，移動体 構成物質に基づくと，熱水変質岩地すべり ${ }^{25}$ に分類でき ると結論した。

(2) 生田原南地すべり防止区域

生田原南地すべり防止区域に扔ける地表熱水変質帯分 布の特徴は, 前期ステージ広域変質带のスメクタイト クリノタイロライト亜帯を切って, 前期ステージ脈際中 性帯のカリ長石一イライト亜帯, カリ長石ーイライト／ スメクタイト混合層鉱物亜带, カリ長石一スメクタイト 亜帯, イライト-石英亜帯, イライトーイライト/スメ クタイト混合層鉱物亜帯抢よびイライト/スメクタイト 混合層鉱物帯（図-6，7）が全体として基岩の生田原層 の走向にほぼ一致するNNW-SSE方向に伸長している ことである(図-6)。

生田原神社地すべり地域における滑落崖の上方斜面地 表から下方斜面地表へ，カリ長石ーイライト/スメクタ イト混合層鉱物亜帯，カリ長石一イライト亜帯，イライ トノスメクタイト混合層鉱物帯およびカリ長石ーイライ トノスメクタイト混合層鉱物亜带がNNW-SSE方向に 伸長して累帯している (図-6)。また，この地すべり Aユニットの縦断面（図一７）に㧍ける地表からの垂直 梁度8.0 14.0m以深の基岩は, $\mathrm{A}$ ユニット脚部の垂直

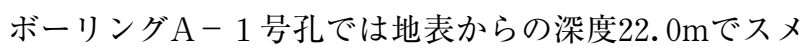
クタイトークリノタイロライト亜帯を切って, カリ長石 ーイライト亜带が見られ，その東側方の $\mathrm{A}$ ユニット胴部 の $\mathrm{A}-2$ 号孔㧍よび頭部の $\mathrm{A}-3$ 号孔と, さらに東側方 の $\mathrm{A}$ ユニット外の $\mathrm{A}-4$ 号孔へ, わずかにカリ長石ーイ ライト亜带を伴うイライトーイライト/スメクタイト混 合層鉱物亜带が带状分布している(図-7)。それゆえ， この地すべりは，これらの変質帯の伸長方向と斜交する
北東から南西へ移動し, 主にイライト/スメクタイト混 合層鉱物を含む熱水変質带で発生した岩首地すべり ${ }^{25}$ で ある（図-7）。

2000年頃に発生した生田原野球場地すべりは, カリ長 石ーイライト/スメクタイト混合層鉱物亜带を基岩とし (表-1)，移動体が主にカリ長石ーイライト带带やイラ イトーイライト/スメクタイト混合層鉱物亜带 (図-6) 起源の土砂からなる土砂地すべり 25)である。

生田原公園地すべり地域には, カリ長石ーイライト亜 带, カリ長石一スメクタイト亜帯拉よびカリ長石ーイラ イトノスメクタイト混合層鉱物亜带が主にNNW - SSE 方向に伸長して累帯している(図-6)。それ沛え，こ の地すべりは，これらの変質帯の伸長方向と斜交する北 東から南西へ移動し，主にイライト／スメクタイト混合 層鉱物やスメクタイトを含むカリ長石帯で発生した岩屑 地すべりである。

F地すべりは, 局所的にカリ長石ーイライト亜带を包 蔵するスメクタイトークリノタイロライト带帯の細粒凝 灰岩を基岩とし（表- 1 , 図- 6 ), 主に風化・熱水変質 岩片や鉱物片を移動体とする岩首地すべりである。

H地すべりは, 局所的にカリ長石一スメクタイト亜带 を包蔵するカリ長石ーイライト带带の細粒凝灰岩を基岩 とし（表 -1 , 図-6)，主にそれらの風化・熱水変質岩 片や鉱物片を移動体とする岩首地すべりである。

C崩壞は, 地表熱水変質带分布図 (図-6) と崩壊面 が植生に打扔われず，露出していることに基づくと，カ リ長石ースメクタイト带带を包蔵するカリ長石ーイライ トノスメクタイト混合層鉱物亜帯（表－1）で発生した 最近の表層崩壊である。

$\mathrm{G}$ 崩壞は, 地表熱水変質带分布図 (図-6) と崩壊面 が植生におおわれていることに基づくと，カリ長石一イ ライト亜带（表一1）で発生した古期表層崩壊である。

\section{5. 結 言}

生田原南地すべり地域の古期大規模地すべりと生田原 南地すべり防止区域における古期中規模および最近の小 規模地すべりの地質的特徴は次のと抢りである。

（1）地すべりは, 基岩地質に基づくと, いずれも熱水 変質带地すべりに分類される。一方, 移動体構成物質に 基づくと, 古期大規模地すべりは熱水変質岩地すべり, また，生田原南地すべり防止区域の中規模地すべりでは, 生田原神社地すべり, 生田原公園地すべり, F地すべり およびH地すべりは岩首地すべり，小規模地すべりでは, 生田原野球場地すべりは土砂地すべりに分類される。

(2) 古期大規模地すべりは, 滑落崖と左側方崖の上部 がカリ長石 - 石英亜帯, イライトー石英亜帯, ディッカ イト帯などの珪化帯とイライトーイライトノスメクタイ 卜混合層鉱物亜带の粘土化帯との境界に規制され，かつ， 移動体頭部〜胴部の基岩における $20^{\circ}$ 以下の流れ盤と, 胴部〜脚部の基岩における $18^{\circ}$ 以下の受け盤の構造に支 
配され，また，局所的に珪化帯を伴うイライトーイライ トノスメクタイト混合層鉱物亜帯やスメクタイトーアナ ルサイト亜帯の熱水性粘土化帯の中の膨潤性粘土鉱物を 含む熱水変質岩をすべり面として発生したと考えられる。 ( 3 ）生田原南地すべり防止区域の古期中規模および最 近の小規模地すべりは，スメクタイトークリノタイロラ イト亜帯と，それを切って基岩の走向とほぼ平行に伸長 して分布するカリ長石帯，イライト帯およびイライト／ スメクタイト混合層鉱物帯において発生しているが，力 リ長石帯やイライト帯においてもイライト／スメクタイ 卜混合層鉱物やスメクタイトを特徵的に含むので，膨潤 性粘土鉱物を含む熱水変質帯と密接な関係を持つと考え られる。

\section{6. 今後の課題}

ボーリングデータのある生田原南地すべり防止区域に おける三次元熱水変質带分布と地下水の分布，流動方向 などの水文地質学的特徵と地すべりとの関係や，熱水変 質岩からなる基岩および移動体における風化帯構造や, 弱風化，中風化および強風化・熱水変質岩の一軸圧縮強 さなどの力学的性質と地すべりとの関係を明らかにする 必要があり，今後の課題である。

\section{謝 辞}

北海道オホーツク総合振興局網走建設管理部の方々に は様々な便宜を図っていただいた。北見工業大学大学院 工学研究科土木開発工学専攻修了生関下慶彦氏には野外 調査やXRD試験にご協力いただいた。担当編集委員の 方々と匿名査読者の方々には建設的なコメントをいただ いた。記して，以上の方々に厚くお礼申し上げる。

\section{引用文献}

1 ) 納谷 宏・植松 聡・牧野彰人・前田宽之・八幡和則 (2005) : 北海道生田原南地すべりの発生機構, 第44回日本地すべり学 会研究発表会講演集, pp. $63-66$.

2 ) 河野勝宣・前田寛之（2010）：軟岩－中硬岩境界領域における スメクタイトを含む細䊉凝灰岩の円柱（縦）点載荷強さと一 軸圧縮強さとの関係一北海道生田原南地すべり移動体の上部 中新統生田原層の例一。目本地すべり学会誌（地すべり）, Vol. 47, No.1, pp. $17-25$.

3 ）前田寛之（1996）：地すべりの地形，地質および変質特性－北 海道紋別郡生田原町東部地域の例一, 地すべり, Vol. 33, No. 1, pp. $1-8$.

4 ）前田寛之（1999）：生田原町生田原地すべり, 地すべり学会北 海道支部北海道の地すべり'99編集小委員会編「北海道の地す べり'99」, 地すべり学会北海道支部, pp. 86-90.

5 ）前田寛之（2002）：地すべりと変質帯（その 1$)$ - 地すべりと 熱水変質带との関係一, 地すべり技術, Vol. 29, No. 1, pp. 29-37.

6 ) Maeda, H., Sasaki, T., Furuta, K., Takashima, K., Umemura, A. and Kohno, M. (2008) : What is a hydrothermal alteration zone landslide? The relationship between ancient landslides and point load strength of hydrothermal alteration zone rocks in Hokkaido, Japan. Proceedings of The First World Landslide Forum, Global Promotion Committee of The Inter- national Programme on Landslides (IPL), pp. 389-392.

7 ) 小出 博 (1955)：日本の地すべり一その予知と対策一, 東洋 経済新報社, 259p.

8 ）安藤 武 (1974）：地すべりの分類と地質特性について, 地す ベり, Vol.11, No.1, pp. 32-36.

9 ) 藤原明敏 (1970)：地すべり調查と解析一実例に基づく調查 · 解析法 -, 理工図書, 222p.

10）山崎 勉・小島 健 - 山崎孝成・小材 徹・横田泰男（2003）: 群馬県万座地域の地すべりと変質, 日本地すべり学会誌（地 すべり), Vol.40, No.1, pp.68-77.

11) Hasegawa, S., Yoshida, Y., Akagi, W, Tamura, E. and Kanbara, D. (2006) : Rock mass characterization for tunnelling by the geological history of hydrothermal alteration and landsliding, IAEG 2006 Paper number 580, pp. 1-13.

12）田村栄治 - 長谷川修一 ・渡辺弘樹 - 宮田和幸 - 矢田部龍一 内田純二（2007）：中央構造線沿いの熱水変質に起因する地す ベり, 日本地すべり学会誌(地すべり), Vol. 44, No. 4, pp. 18 -32 .

13）前田寛之（1988）：北海道生田原地すべり地の崩積土とすべり 面粘土，地すべり，Vol.25，No.1，pp.13-20.

14）前田寛之（1994）：熱水性脈状粘土化帯と地すべりとの密接な 関係－北海道金華峠地すべりの例－，地すべり，Vol. 31，No. 1， pp. $21-28$.

15) Maeda, H.(1994) : The close relationship between the Yasukuni Slide and a hydrothermal interstratified sericite/ smectite zone. Proceedings of The Northeast Asia Symposium and Field Workshop on Landslides and Debris Flows, pp. $349-356$.

16）前田寛之・鈴木俊司・登嶋弘人・山田 司（1996）：熱水変質 带地すべり一北海道常呂郡留辺藥町金華地すべり地域の例一, 地すべり, Vol. 33, No.3, pp. 19-24.

17）前田寛之（1996）：熱水変質帯地すべり - 北海道紋別郡生田原 町仁田布川流域の例一, 地すべり, Vol. 33, No3, pp. 8-12.

18）前田寛之・佐々木 悟（1997）：熱水変質帯地すべり－北海道 川上郡弟子屈町札友内 - 奥春別地すべり 地域の例 - ，地す心゙ り, Vol. 33, No.4, pp. 20-25.

19) Maeda, H. and Hiura, H. (1999) : The Iwato Slide has characteristics of both shear zone slide and hydrothermal alteration zone slide. Landslides - J. of the Jpn. Landslide Soc., Vol. 36 , No. 2, pp. $24-31$.

20) Maeda, H. and Hiura, H.(2001) : The relationship between the Yasukuni Slide and a hydrothermal interstratified illite/ smectite minerals zone. Landslides - J. of the Jpn. Landslide Soc., Vol. 37, No. 4, pp. $1-9$.

21）前田寛之 ·大口伸生・松本尚巳（2001）：北海道常呂郡留辺葙 町金華地すべり地域における地すべりハザードマッピング, 地すべり, Vol. 38, No.1, pp. 61-68.

22）前田寛之（2006）: 熱水変質帯地すべりと熱水変質岩の点載荷 強度との関係一東部北海道弟子屈町奥春別地すべり地域およ び遠軽町生田原南地すべり地域の例 - ，平成18年度（社）日 本地すべり学会シンポジゥム講演集, pp. 39-46.

23）河野勝宣・前田寬之（2011）：点載荷強さ試験に基づく熱水変 質岩の力学特性 - 北海道北東部地域の例 -, Journal of MMIJ, Vol. 127, No.1, pp. 14-19.

24) Maeda, H.(1996) : Relationship between volcanic activity and epithermal gold-silver mineralization: Example from Kitano-oh mine area and vicinity in Kitami metallogenic province, Hokkaido, Japan, Resource Geol., Vol. 46, No. 5, pp. $279-285$.

25）前田寛之（2008）：地すべり学の発展のため, 北海道において, 今後, 何をすべきか?, 北海道地すべり学会・(社) 日本地す ベり学会北海道支部30周年記念事業実行委員会編CD資料集 「北海道の地すべり研究30年」, pp. $1-10$.

（原稿受付2010年10月12日，原稿受理2011年 4 月21日） 